\title{
Early Island-Arc Intrusive Activity, Cordillera Central, Dominican Republic
}

\author{
Stephen E. Kesler ${ }^{1 *}$, John F. Lewis ${ }^{2}$, Lois M. Jones ${ }^{3}$, and Raymond L. Walker ${ }^{4}$ \\ ${ }^{1}$ Department of Geology, University of Toronto, Toronto, Ontario, Canada \\ ${ }^{2}$ Department of Geology, George Washington University, Washington, D.C., USA \\ ${ }^{3}$ Department of Geology, University of Georgia, Athens, Georgia, USA \\ ${ }^{4}$ Oak Ridge National Laboratory, Oak Ridge, Tennessee, USA
}

\begin{abstract}
Reconnaissance studies of early island-arc intrusions in the Cordillera Central of the Dominican Republic demonstrate that these rocks are mainly hornblende tonalite with lesser amounts of hornblende diorite, quartz diorite, granodiorite and quartz monzonite. Two plutons (El Bao, Medina) are petrographically and chemically homogeneous, whereas two others (E1 Rio and Loma de Cabrera) are compositionally heterogeneous. Samples from these intrusions range in $\mathrm{SiO}_{2}$ from 49 to $70 \%$ with most rocks in the 59 to $62 \%$ range. $\mathrm{K}_{2} \mathrm{O}$ ranges from 0.24 to $3 \%$ and averages $1.2 \% . \mathrm{Cu}, \mathrm{Zn}, \mathrm{Co}, \mathrm{Ni}, \mathrm{V}$ and possibly $\mathrm{Cr}$ decrease with increasing $\mathrm{SiO}_{2}$. $\mathrm{Rb} / \mathrm{Sr}$ values for the intrusions are low but variable. Present-day ${ }^{87} \mathrm{Sr} /{ }^{86} \mathrm{Sr}$ values range from 0.7031 to 0.7045 for the El Bao and Loma de Cabrera batholiths and 0.7033 to 0.7091 for the Medina stock. These data do not generate isochrons. The Cordillera Central tonalite intrusions are the most abundant plutonic rock type in the Greater Antilles, although small, younger granodiorite and quartz monzonite stocks are present. The Cordillera Central intrusions are lower in $\mathrm{SiO}_{2}$, $\mathrm{K}_{2} \mathrm{O}, \mathrm{Rb}$, and $\mathrm{Sr}$ than the average composition of the Sierra Nevada batholith, but they are similar to the tonalites and trondjhemites from the western margin of the Sierra Nevada batholith. The low $\mathrm{Rb} / \mathrm{Sr}$ ratios and low initital $\mathrm{Sr}^{87} / \mathrm{Sr}^{86}$ ratios for the Cordillera Central intrusions combined with the high liquidus temperatures required for the generation of tonalite magmas strongly favor a subcrustal source for these magmas in an island-arc setting.
\end{abstract}

\section{Introduction}

Although considerable attention has been given to the characteristics and origin of igneous rocks in

* Present address: Department of Geology and Mineralogy, University of Michigan, Ann Arbor, MI 48109, USA oceanic island arcs, almost all of this work has focussed on the volcanic rocks. The intrusive rocks, which make up at least ten percent of the exposed igneous assemblage, and which are markedly more quartz-rich than the volcanic rocks, have received comparatively little attention. It is the purpose of this paper to consider the nature and origin of these island arc intrusive rocks by focussing on the earliest and most voluminous intrusive units in the Greater Antilles island arc, the tonalites of the Cordillera Central in the Dominican Republic.

Samples used in this study were collected by Kesler and Lewis in 1972 and 1973 largely along roads and jeep trails. No effort was made to delineate individual pluton boundaries within batholiths, and few contacts were seen. All samples used in this study weighed between 2 and $5 \mathrm{~kg}$. Major (Lewis) and trace (Kesler) element analyses (except $\mathrm{Rb}$ and $\mathrm{Sr}$ ) were done by atomic absorption methods using U.S.G.S. analyzed rocks as standards for major elements and synthetic standards for trace elements. Standard addition techniques were used for $\mathrm{Co}, \mathrm{Cr}$, and $\mathrm{Ni}$ and background corrections were made for $\mathrm{Co}, \mathrm{Cr}, \mathrm{Ni}$, and $\mathrm{Pb} . \mathrm{Sr}$ for the isotope analyses (Jones, Walker) was separated from the rock by $\mathrm{HF}-\mathrm{HNO}_{3}-\mathrm{H}_{2} \mathrm{SO}_{4}$ dissolution and cation-exchange chromatography. The ${ }^{87} \mathrm{Sr} /{ }^{86} \mathrm{Sr}$ ratio was determined in a two-stage, 12-inch radius, $90^{\circ}$ deflection, solid source mass spectrometer at Oak Ridge National Laboratory. $\mathrm{Rb}$ and $\mathrm{Sr}$ concentrations were determined in replicate by $\mathrm{X}$ ray fluorescence using silicate standards of similar composition, in which the $\mathrm{Rb}$ and $\mathrm{Sr}$ contents had been determined previously by isotope dilution techniques.

\section{Geological Setting of the Tonalite Intrusions}

\section{Regional Geologic Framework}

The Dominican Republic occupies the eastern two-thirds of the island of Hispaniola (Fig. 1) which, along with Cuba, Jamaica, 


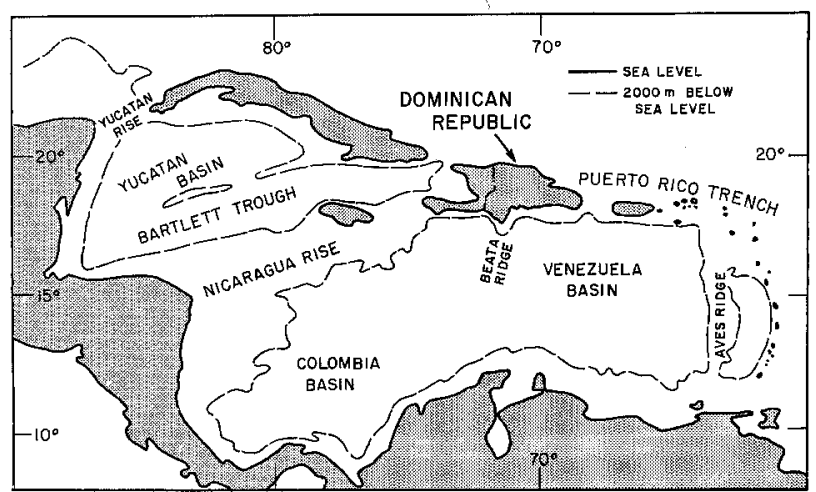

Fig. 1. Location of the Dominican Republic in relation to topographic and tectonic features in the northern Caribbean region

Puerto Rico and the Virgin Islands, makes up the Greater Antilles. The western half of the Greater Antilles consists of at least two separate arcs, the Nicaragua Rise-Jamaica trend and the Cuba trend, which merge in Hispaniola. The basement on which these arcs were built appears to be largely Jurassic sea floor (Khudoley and Meyerhoff, 1971; Cox et al., 1977; Kesler et al., 1977a). With the exception of western Cuba, the Greater Antilles have undergone at least two major tectonic cycles. The early phase, which is of interest in this study, involved construction of a submarine and later emergent volcanic pile (Donnelly et al., 1971) and concomitant sedimentation. This phase was punctuated by several periods of intrusive activity, the first and largest of which probably took place at about $75 \pm 10 \mathrm{~m} . \mathrm{y}$. The intrusions considered in this report were emplaced at that time. Near the end of the Eocene, the intensity of igneous activity characterizing the first tectonic phase diminished drastically and the second phase began. It was characterized by extensive volcaniclastic and carbonate sedimentation with minor, but locally significant volcanic activity (Weyl, 1966) and is still underway.

Although the plate tectonic configuration during the early evolution of the Greater Antilles remains a matter of debate (Malfait and Dinkelman, 1972; Burke and Fox, 1976) there is local evidence for an early Cretaceous northward-dipping subduction zone in the Dominican Republic. Bowin (1975) notes that the Cordillera Central of the Dominican Republic (Fig. 2), which is the locus of the intrusions included in this study is divided longitudinally by a northwest-trending body of serpentinized peridotite. Southwest of this serpentinite are metamorphosed mafic volcanic rocks of the Duarte Formation and to the northeast are metamorphosed quartz-bearing rocks of the Maimon and Aminas Formations. These units are interpreted to represent basaltic seafloor (Duarte) and early island-arc volcanic rocks (Maimon-Aminas) joined along a paleosubduction zone that originally dipped northward beneath the Maimon-Aminas rocks (Bowin, 1975, p. 540). Kesler et al. (1977a) have obtained concordent hornblende-plagioclase K-Ar ages of $125 \mathrm{~m}$.y. for amphibolite in rocks interpreted to be part of the Duarte Formation and a model lead age of approximately 130 m.y. for galena in veinlets deposited within and during the latest phase of volcanic activity in the Los Ranchos Formation, a volcanic unit that contains quartz keratophyre similar to that in the Maimon and Aminas Formations. Thus, this subduction zone probably operated in Late Cretaceous time. Whether or not it continued in activity until the emplacement of the tonalites at $75 \pm 10$ m.y. is not known.

In their original mapping of the Cordillera Central, both Bowin (1966, p. 66) and Palmer (1963, p. 206) divided the tonalite intrusions into two groups. Unfoliated tonalites are by far the most abundant in size and number of intrusions. They are massive in outcrop and lack pronounced contact aureoles. Foliated tonalites form smaller and less abundant intrusions with marginal to throughgoing foliation and well-developed contact aureoles. Bowin (1966) noted that the foliated tonalites are found only in the Duarte Formation, whereas the unfoliated tonalites are found in both the Duarte Formation and younger rocks and concluded from this that the unfoliated tonalites were probably younger than the foliated tonalites. Because of their fabric, the foliated tonalites weather rapidly and provide very few samples suitable for chemical study. The unfoliated tonalites are exposed in relatively widespread fresh outcrops and can be sampled conveniently. Accordingly, we have confined our attention to the unfoliated tonalites and will benceforth refer to them simply as tonalites. We estimate, largely from the data of Bowin (1966), Palmer (1963) and Blesch (1967), that these (unfoliated) tonalite intrusions account for $90 \%$ of the volume of intrusive rocks in the Cordillera Central.

We have sampled four intrusions for this study, the Medina stock and the EI Bao, El Rio and Loma de Cabrera batholiths. On the basis of contact relations (Bowin, 1966; Palmer, 1963; Blesch, 1967), all of these intrusions appear to be Late Cretaceous in age. Bowin (1975, Table 3) lists a K-Ar age of $86 \pm 3$ m.y. for

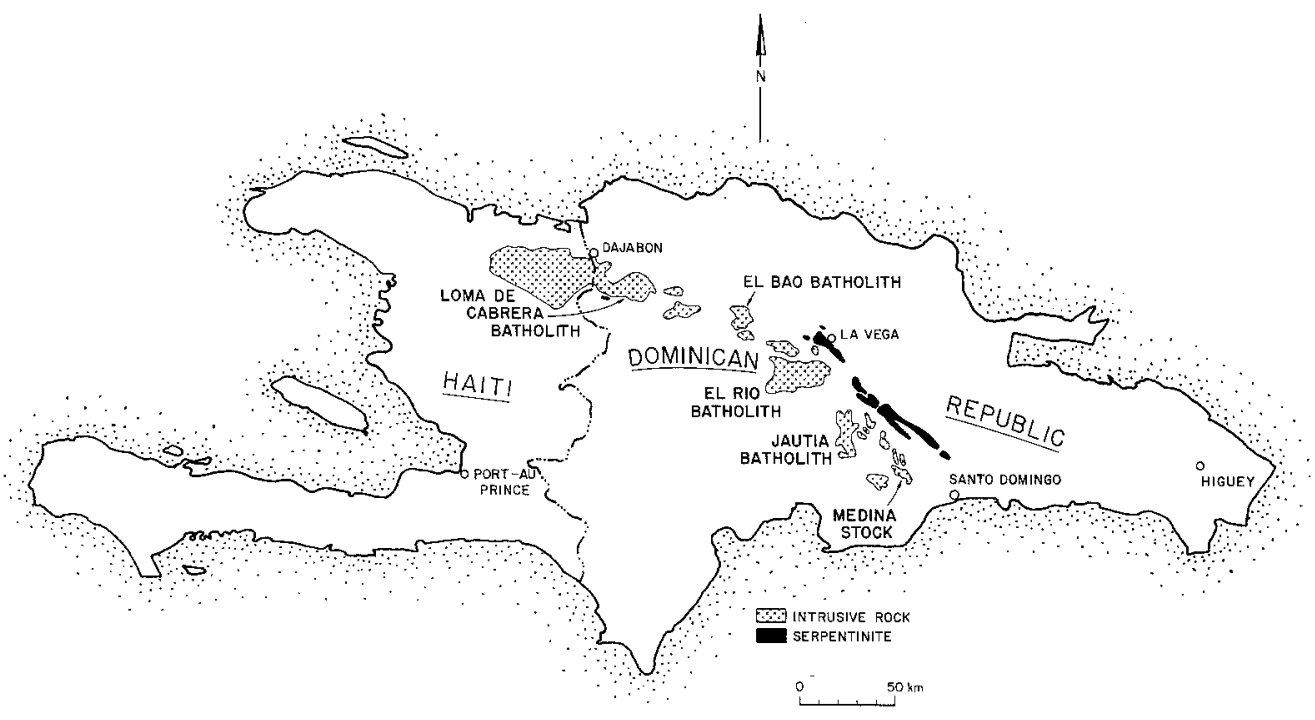

Fig. 2. Distribution of intrusive rocks in the Cordillera Central of the Dominican Republic and the adjacent Massif du Nord in Haiti showing location of intrusive bodies mentioned in the text 
the El Rio batholith. Preliminary interpretation of other K-Ar ages obtained by Kesler et al. on the Medina stock and El Bao and Loma de Cabrera batholiths indicates Late Cretaceous emplacement for all of the samples included in this study. No definitive isotopic ages are available for the foliated tonalites.

\section{Petrography of the Tonalites}

The four tonalite intrusions are largely mediurn-grained and equigranular to slightly porphyritic. The mineral assemblage observed is plagioclase + hornblende + quart \pm biotite \pm orthoclase (Table 1). Plagioclase and hornblende began to crystallize first and were followed by biotite, quartz, and orthoclase, usually in that order. Quartz, plagioclase, and orthoclase (where present) were the last minerals to form. In most rocks containing both biotite and hornblende, biotite continued to crystallize after hornblende crystallization had ceased. In porphyritic rocks, phenocrysts are hornblende and/or plagioclase. The Medina and El Bao intrusions are largely orthoclase-free tonalite (Fig. 3), whereas the El Rio and Loma de Cabrera intrusions range in composition from hornblende diorite to quartz-rich granodiorite. Orthoclase-mafic-mineral associations in the two groups differ also, with the El Rio and Loma de Cabrera batholiths containing more orthoclase and less biotite.

These intrusions display varying degrees of compositional zoning. Biotite appears to increase relative to hornblende from north to south in the Medina stock. The El Bao batholith, although generally homogeneous, exhibits biotite enrichment near its core. The margins of the El Rio batholith are largely hornblende tonalite or hornblende diorite, whereas the north-central portion is more granodioritic. The Loma de Cabrera batholith, which extends westward into the Massif du Nord of Haiti (Cheilletz and Lewis, 1975) is the most complex of the plutons in the Cordillera Central. Foliated biotite-hornblende tonalite, a variety not seen in other intrusions, forms much of the northeastern part of the batholith and several bodies of leucocratic tonalite are present in the western part of the batholith along the Haiti-Dominican Republic border. Granodiorite is abundant in the northcentral part of the batholith.

\section{Chemistry of the Tonalite Intrusions}

Major-element chemical compositions of the four Dominican Republic tonalite intrusions (Table 1) exhibit some differences, as discussed below, but are generally similar. Silica abundances for all rock types range from 50 to $78 \%$ with most analyses in the 59 to $67 \%$ range. The combined data define a $\mathrm{K}_{2} \mathrm{O}$ $\mathrm{SiO}_{2}$ trend (Fig. 4) yielding $0.3,1.0$ and $1.7 \% \mathrm{~K}_{2} \mathrm{O}$ at $\mathrm{SiO}_{2}$ abundances of 50,60 and $70 \%$, respectively. The wide spread of $\mathrm{K}_{2} \mathrm{O}$ values for high $\mathrm{SiO}_{2}$ values (Fig. 4), reflects the presence of both potassic granodiorites and trondjhemites among the more silicic members of the tonalite group. $\mathrm{K}_{2} \mathrm{O} / \mathrm{Na}_{2} \mathrm{O}$ ratios range from 0.10 to 0.61 and average 0.32 .

Classification of the Dominican Republic tonalites is ambiguous with respect to the commonly used term, calc-alkaline and tholeiitic. On an alkali-lime plot (Peacock, 1931), the combined data define trends (Fig. 4) that intersect at $68 \% \mathrm{SiO}_{2}$, which is well within the calcic field. On the iron-magnesium plots
MODAL COMPOSITION OF INTRUSIVE ROCKS CORDILLERA CENTRAL, DOMINICAN REPUBLIC
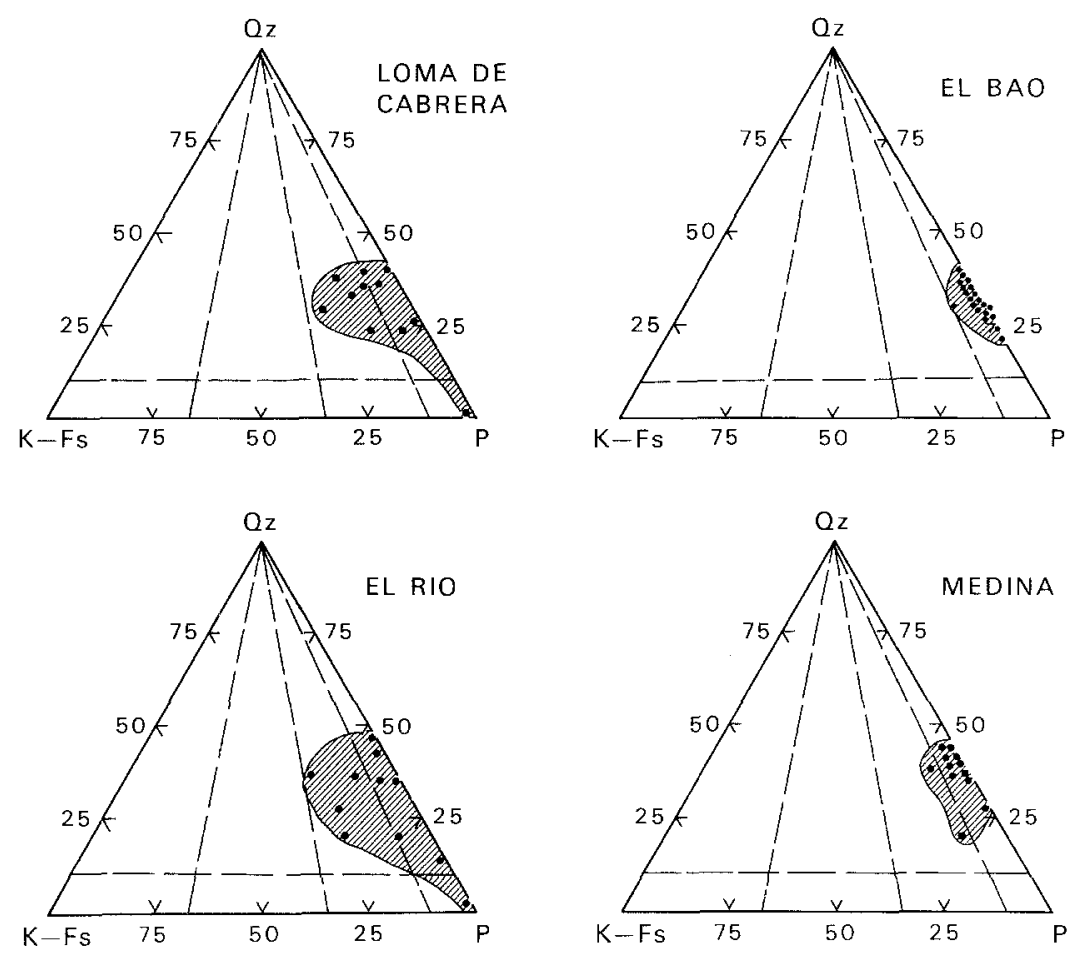

Fig. 3. Variation of modal quartz, $\mathrm{K}$-feldspar and plagioclase in the four intrusive bodies described in this report 
Table 1. Chemical and modal analyses of tonalite intrusions in the Dominican Republic

\begin{tabular}{|c|c|c|c|c|c|c|c|c|c|}
\hline & \multicolumn{9}{|c|}{ Medina Stock } \\
\hline & RD-72-1 & RD-72-2 & $\mathrm{RD}-72-3$ & RD-72-4 & $\mathrm{RD}-72-6$ & RD-72-8 & RD-72-9 & RD-72-10 & RD-72-12 \\
\hline $\mathrm{SiO}_{2}$ & 63.7 & 60.9 & 62.5 & 64.4 & 61.5 & 60.3 & 63.1 & 64.7 & 66.1 \\
\hline $\mathrm{Al}_{2} \mathrm{O}_{3}$ & 16.9 & 16.9 & 16.7 & 15.2 & 15.8 & 16.4 & 17.4 & 14.9 & 15.0 \\
\hline $\mathrm{TiO}_{2}$ & 0.48 & 0.52 & 0.5 & 0.82 & 0.9 & 1.0 & 1.1 & 0.97 & 0.98 \\
\hline $\mathrm{Fe}_{2} \mathrm{O}_{3}{ }^{\mathrm{a}}$ & 5.6 & 4.7 & 4.9 & 5.0 & 3.6 & 5.8 & 6.1 & 6.1 & 6.0 \\
\hline $\mathrm{MnO}$ & & 0.1 & 0.11 & 0.09 & 0.11 & 0.11 & 0.12 & 0.11 & 0.12 \\
\hline $\mathrm{MgO}$ & 2.5 & 2.5 & 2.5 & 2.6 & 2.5 & 2.5 & 2.0 & 2.71 & 3.0 \\
\hline $\mathrm{CaO}$ & 6.0 & 7.4 & 7.8 & 6.1 & 8.7 & 9.0 & 5.9 & 6,2 & 4.1 \\
\hline $\mathrm{Na}_{2} \mathrm{O}$ & 4.1 & 3.9 & 3.8 & 4.3 & 4.3 & 3.4 & 3.2 & 3.6 & 3.8 \\
\hline $\mathrm{K}_{2} \mathrm{O}$ & 1.7 & 1.3 & 1.3 & 0.65 & 1.1 & 0.98 & 0.74 & 1.1 & 1.1 \\
\hline $\mathrm{H}_{2} \mathrm{O}^{+}$ & & 0.4 & 0.8 & 1.0 & 1.0 & 0.5 & 0.5 & 0.4 & 0.3 \\
\hline Total & 101.0 & 98.6 & 100.9 & 100.2 & 99.5 & 100.0 & 100.2 & 100.8 & 100.5 \\
\hline $\mathrm{Cu}$ & 16 & 51 & 12 & 6 & 31 & 85 & 75 & 90 & 80 \\
\hline $\mathrm{Zn}$ & 57 & 49 & 49 & 30 & 5 & 57 & 56 & 53 & 28 \\
\hline $\mathrm{Pb}$ & 7 & 5 & - & 6 & 56 & - & 6 & 6 & 3 \\
\hline Co & 13 & 13 & 14 & 10 & 15 & 8 & 10 & 10 & 10 \\
\hline $\mathrm{Ni}$ & 15 & 17 & 13 & 16 & 14 & 13 & 19 & 16 & 20 \\
\hline $\mathrm{Cr}$ & 38 & 30 & 46 & 39 & 10 & - & - & - & - \\
\hline $\mathrm{V}$ & - & 137 & - & - & 107 & - & 150 & 137 & - \\
\hline $\mathrm{QZ}$ & 15 & 33 & - & 42 & 31 & 25 & 25 & 24 & 34 \\
\hline PL & 56 & 43 & - & 47 & 53 & 54 & 54 & 40 & 46 \\
\hline $\mathrm{KF}$ & 7 & 6 & - & $\operatorname{tr}$ & $\operatorname{tr}$ & $\operatorname{tr}$ & $\mathrm{tr}$ & 2 & - \\
\hline $\mathrm{HB}$ & 18 & 11 & - & 10 & 14 & 13 & 13 & 19 & 10 \\
\hline BI & 2 & 6 & - & - & 1 & 7 & 7 & 14 & 10 \\
\hline PX & - & - & - & - & - & - & - & - & - \\
\hline \multirow[t]{3}{*}{$\mathrm{MG}$} & 2 & 1 & - & 1 & 1 & - & 1 & 1 & - \\
\hline & \multicolumn{9}{|c|}{ El Rio Batholith } \\
\hline & RD-72-50 & RD-72-51 & RD-72-52B & RD-72-53A & RD-72-54A & RD-72-55A & RD-72-62 & RD-72-63 & RD-72-64A \\
\hline $\mathrm{SiO}_{2}$ & 69.4 & 72.6 & 72.8 & 60.2 & 65.3 & 68.1 & 49.8 & 60.5 & 71.4 \\
\hline $\mathrm{Al}_{2} \mathrm{O}_{3}$ & 13.3 & 12.9 & 13.2 & 12.8 & 16.3 & 15.6 & 15.0 & 16.0 & 13.9 \\
\hline $\mathrm{TiO}_{2}$ & 0.33 & 0.39 & 0.46 & 0.46 & 0.56 & 0.59 & 0.57 & 0.46 & 0.20 \\
\hline $\mathrm{Fe}_{2} \mathrm{O}_{3}{ }^{2}$ & 4.3 & 2.6 & 3.1 & 9.8 & 3.9 & 4.2 & 7.4 & 6.7 & 1.3 \\
\hline $\mathrm{MnO}$ & 0.07 & 0.07 & 0.08 & 0.14 & 0.09 & 0.09 & 0.15 & 0.15 & 0.11 \\
\hline $\mathrm{MgO}$ & 1.1 & 1.1 & 1.3 & 5.3 & 1.7 & 2.2 & 7.0 & 1.2 & 1.4 \\
\hline $\mathrm{CaO}$ & 7.4 & 4.5 & 4.7 & 7.1 & 4.9 & 5.9 & 16.2 & 9.9 & 2.4 \\
\hline $\mathrm{Na}_{2} \mathrm{O}$ & 3.3 & 4.1 & 3.6 & 2.2 & 4.3 & 2.4 & 2.4 & 3.7 & 4.9 \\
\hline $\mathrm{K}_{2} \mathrm{O}$ & 0.32 & 1.4 & 0.99 & 1.0 & 1.3 & 0.31 & 0.5 & 0.65 & 3.0 \\
\hline $\mathrm{H}_{2} \mathrm{O}^{+}$ & 0.8 & 0.7 & 0.7 & 0.8 & 1.7 & 1.6 & 1.3 & 0.8 & 0.8 \\
\hline Total & 100.3 & 100.4 & 100.9 & 99.8 & 100.1 & 101.0 & 100.3 & 100.1 & 99.4 \\
\hline $\mathrm{Cu}$ & 14 & 19 & - & - & - & - & 70 & 35 & - \\
\hline $\mathrm{Zn}$ & 27 & 43 & - & - & - & - & 65 & 71 & - \\
\hline $\mathrm{Pb}$ & 2 & 2 & 3 & 6 & 7 & 4 & - & - & - \\
\hline $\mathrm{Co}$ & - & 2 & 4 & 23 & 7 & 11 & 25 & 24 & - \\
\hline $\mathrm{Ni}$ & 4 & 17 & 4 & 25 & 30 & 25 & 58 & 26 & - \\
\hline $\mathrm{Cr}$ & 6 & 13 & 12 & - & 43 & 63 & - & 7 & - \\
\hline $\mathrm{V}$ & 67 & 50 & 85 & 175 & 92 & 97 & - & - & - \\
\hline $\mathrm{QZ}$ & 44 & 21 & 32 & 25 & 20 & 34 & - & 15 & 31 \\
\hline PL & 53 & 65 & 55 & 37 & 40 & 48 & - & 42 & 44 \\
\hline $\mathrm{KF}$ & - & 8 & 5 & 6 & 13 & - & - & 13 & 22 \\
\hline $\mathrm{HB}$ & 2 & 1 & 4 & 30 & 27 & 18 & - & 30 & 1 \\
\hline BI & 1 & 5 & 4 & 2 & - & - & - & - & 2 \\
\hline PX & - & - & - & - & - & - & - & - & - \\
\hline $\mathrm{MG}$ & - & - & - & - & - & $\operatorname{tr}$ & - & - & $\operatorname{tr}$ \\
\hline
\end{tabular}

a Total $\mathrm{Fe}$ as $\mathrm{Fe}_{2} \mathrm{O}_{3}$ 
Table 1 (continued): Chemical and modal analyses of tonalite intrusions in the Dominican Republic

\begin{tabular}{|c|c|c|c|c|c|c|c|c|}
\hline & \multicolumn{8}{|c|}{ Loma de Cabrera Batholith } \\
\hline & RD-72-28 & RD-72-30 & RD-72-31 & RD-72-35 & RD-72-36 & RD-72-39 & RD-72-40 & RD-72-41 \\
\hline $\mathrm{SiO}_{2}$ & 69.0 & 51.3 & 77.6 & 65.6 & 65.7 & 66.4 & 72.4 & 64.8 \\
\hline $\mathrm{Al}_{2} \mathrm{O}_{3}$ & 15.4 & 14.9 & 13.3 & 15.0 & 14.9 & 14.2 & 13.8 & 14.5 \\
\hline $\mathrm{TiO}_{2}$ & 0.23 & 1.1 & 0.30 & 0.32 & 0.28 & 0.22 & 0.13 & 0.23 \\
\hline $\mathrm{Fe}_{2} \mathrm{O}_{3}^{\mathrm{a}}$ & 3.6 & 12.3 & 0.18 & 5.2 & 5.2 & 6.1 & 3.6 & 6.8 \\
\hline $\mathrm{MnO}$ & 0.08 & 0.21 & 0.03 & 0.11 & 0.12 & 0.13 & 0.10 & 0.14 \\
\hline $\mathrm{MgO}$ & 1.4 & 6.5 & 0.00 & 2.1 & 2.0 & 2.7 & 1.3 & 2.8 \\
\hline $\mathrm{CaO}$ & 5.0 & 10.1 & 0.91 & 5.2 & 4.5 & 5.4 & 3.6 & 5.6 \\
\hline $\mathrm{Na}_{2} \mathrm{O}$ & 3.4 & 2.7 & 4.3 & 3.5 & 3.5 & 2.7 & 3.7 & 3.7 \\
\hline $\mathrm{K}_{2} \mathrm{O}$ & 0.94 & 0.24 & 2.5 & 1.3 & 1.7 & 1.1 & 1.5 & 0.87 \\
\hline $\mathrm{H}_{2} \mathrm{O}^{+}$ & 1.7 & 0.30 & 0.89 & 0.63 & 0.98 & 0.59 & 0.49 & 0.95 \\
\hline Total & 100.8 & 99.7 & 100.0 & 99.0 & 98.9 & 99.5 & 100.6 & 100.4 \\
\hline $\mathrm{Cu}$ & 8 & 65 & 6 & 11 & 10 & 26 & 12 & 26 \\
\hline $\mathrm{Zn}$ & 46 & - & 12 & 42 & 42 & 49 & 31 & 56 \\
\hline $\mathrm{Pb}$ & 18 & 2 & 8 & 3 & 4 & 4 & 6 & 5 \\
\hline $\mathrm{Co}$ & 8 & 37 & - & 13 & 17 & 18 & 4 & 20 \\
\hline $\mathrm{Ni}$ & 1 & 38 & - & 9 & 10 & 18 & 8 & 16 \\
\hline $\mathrm{Cr}$ & 11 & - & 6 & 21 & - & 61 & 6 & 51 \\
\hline V & - & 252 & 99 & 100 & 122 & 135 & 67 & 150 \\
\hline $\mathrm{QZ}$ & 34 & 13 & 28 & 34 & 29 & 26 & 33 & 20 \\
\hline $\mathrm{PL}$ & 54 & 36 & 50 & 42 & 52 & 46 & 43 & 53 \\
\hline $\mathrm{KF}$ & - & - & 20 & 6 & 7 & 9 & 11 & 11 \\
\hline $\mathrm{HB}$ & - & 48 & - & 17 & 12 & 25 & 10 & 13 \\
\hline BI & 11 & - & 2 & - & - & $\operatorname{tr}$ & 2 & 1 \\
\hline PX & - & - & - & - & - & - & - & - \\
\hline \multirow[t]{3}{*}{$\mathrm{MG}$} & $\operatorname{tr}$ & 3 & - & 1 & $\mathrm{tr}$ & 1 & 1 & - \\
\hline & \multicolumn{8}{|c|}{ El Bao Batholith } \\
\hline & RD-72-42 & RD-72-43 & RD-72-44 & RD-72-45 & $\mathrm{RD}-72-46$ & \multicolumn{2}{|l|}{$\mathrm{RD}-72-47$} & \\
\hline $\mathrm{SiO}_{2}$ & 63.3 & 63.0 & 62.8 & 59.2 & 59.4 & 61.6 & & \\
\hline $\mathrm{Al}_{2} \mathrm{O}_{3}$ & 14.4 & 15.6 & 14.8 & 13.9 & 16.0 & 15.3 & & \\
\hline $\mathrm{TiO}_{2}$ & 0.36 & 0.45 & 0.52 & 0.72 & 0.63 & 0.65 & & \\
\hline $\mathrm{Fe}_{2} \mathrm{O}_{3}{ }^{2}$ & 4.7 & 5.9 & 7.0 & 8.7 & 8.6 & 6.8 & & \\
\hline $\mathrm{MnO}$ & 0.10 & 0.14 & 0.14 & 0.19 & 0.16 & 0.16 & & \\
\hline $\mathrm{MgO}$ & 2.2 & 3.3 & 3.5 & 3.9 & 2.9 & 3.1 & & \\
\hline $\mathrm{CaO}$ & 7.7 & 5.6 & 5.8 & 7.1 & 6.9 & 6.5 & & \\
\hline $\mathrm{Na}_{2} \mathrm{O}$ & 2.9 & 4.0 & 3.7 & 3.3 & 3.3 & 3.7 & & \\
\hline $\mathrm{K}_{2} \mathrm{O}$ & 1.7 & 1.6 & 1.5 & 0.79 & 1.1 & 1.1 & & \\
\hline $\mathrm{H}_{2} \mathrm{O}^{+}$ & 0.4 & 0.64 & 0.1 & 0.64 & 0.6 & 0.6 & & \\
\hline Total & 97.8 & 100.2 & 99.9 & 98.4 & 99.6 & 99.5 & & \\
\hline $\mathrm{Cu}$ & 45 & 16 & 34 & 79 & 69 & 17 & & \\
\hline $\mathrm{Zn}$ & 50 & 55 & 57 & - & - & 63 & & \\
\hline $\mathrm{Pb}$ & 6 & 8 & 6 & 8 & 11 & 10 & & \\
\hline $\mathrm{Co}$ & 6 & 16 & 17 & 14 & 17 & 17 & & \\
\hline $\mathrm{Ni}$ & 9 & 12 & 14 & 7 & 15 & 12 & & \\
\hline $\mathrm{Cr}$ & 32 & 37 & 39 & 40 & 31 & 25 & & \\
\hline $\mathrm{V}$ & 132 & 135 & 180 & 225 & 190 & 170 & & \\
\hline $\mathrm{QZ}$ & 34 & 31 & - & 28 & 23 & - & & \\
\hline PL & 62 & 50 & - & 52 & 60 & - & & \\
\hline $\mathrm{KF}$ & $\operatorname{tr}$ & 0 & - & $\operatorname{tr}$ & 0 & - & & \\
\hline $\mathrm{HB}$ & - & 14 & - & 21 & 10 & - & & \\
\hline BI & 4 & 4 & - & 2 & 1 & - & & \\
\hline PX & - & - & - & - & - & - & & \\
\hline $\mathrm{MG}$ & - & 1 & - & 1 & $\mathrm{t} r$ & - & & \\
\hline
\end{tabular}

a Total $\mathrm{Fe}$ as $\mathrm{Fe}_{2} \mathrm{O}_{3}$ 


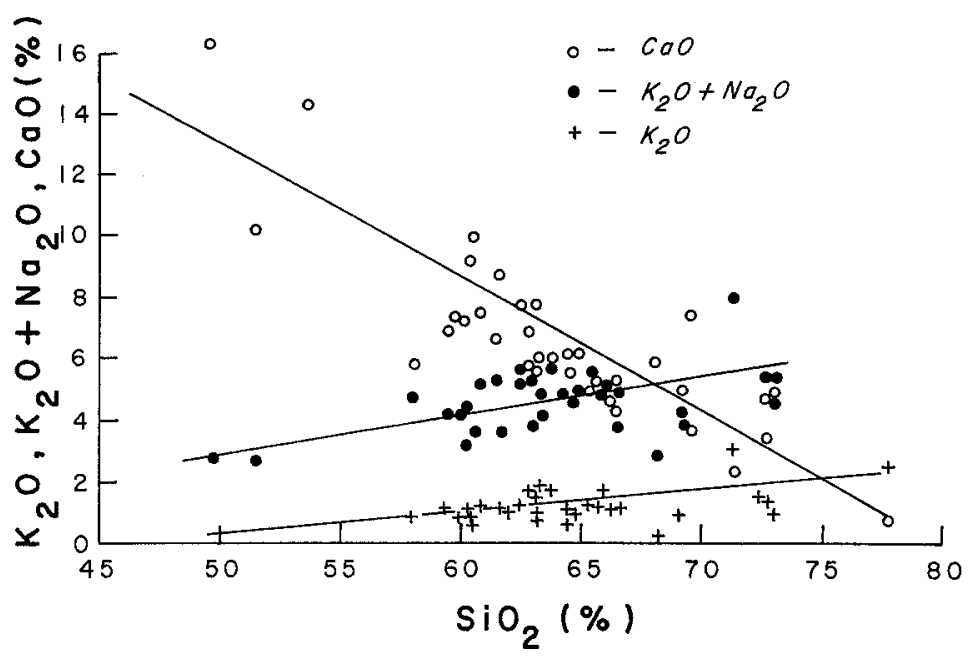

Fig. 4. Variation of $\mathrm{K}_{2} \mathrm{O}, \mathrm{K}_{2} \mathrm{O}+\mathrm{Na}_{2} \mathrm{O}$ and $\mathrm{CaO}$ with $\mathrm{SiO}_{2}$ in combined data for the four tonalite intrusions discussed in the text of Miyashiro (1974) the tonalite intrusions plot in the calc-alkaline field. In comparison to average calcalkaline rocks (Jakes and White, 1972) however, the tonalite intrusions are depleted in aluminum and alkalies and enriched in iron and calcium.

Although average compositions of the four tonalite bodies are similar (Table 2), they can be divided into chemically homogeneous bodies (Medina, El Bao) and chemically heterogeneous bodies (El Rio, Loma de Cabrera). Further distinction can be made between the El Rio and Loma de Cabrera batholiths in that on Harker-type variation diagrams, all Loma de Cabrera rocks fall on a single trend whereas the El Rio rocks fall on two discrete trends, reflecting an as yet undelineated composite nature for this batholith. The previously mentioned trondjhemites form the low- $\mathrm{K}_{2} \mathrm{O}$ group in the El Rio batholith. With the exception of this group all of the tonalite bodies yield alkali-lime plot intersections at approximately $68 \% \mathrm{SiO}_{2}$, as do the combined data for all units, shown in Figure 4.

Trace-element data for the tonalites (Table 1) extend over a wide abundance range but, for the most

Table 2. Averages of chemical analyses of the Medina, El Rio, El Bao and Loma de Cabrera intrusions

\begin{tabular}{lrrrl}
\hline & Medina & El Rio & El Bao & $\begin{array}{l}\text { Loma } \\
\text { de Cabrera }\end{array}$ \\
\hline $\mathrm{SiO}_{2}$ & 63.0 & 65.6 & 61.0 & 65.4 \\
$\mathrm{Al}_{2} \mathrm{O}_{3}$ & 16.1 & 14.3 & 15.0 & 15.0 \\
$\mathrm{TiO}_{2}$ & 0.8 & 0.5 & 0.6 & 0.4 \\
$\mathrm{Fe}_{2} \mathrm{O}_{3}$ & 5.3 & 4.8 & 6.9 & 5.7 \\
$\mathrm{MnO}$ & 0.1 & 0.1 & 0.1 & 0.1 \\
$\mathrm{MgO}$ & 2.5 & 2.5 & 3.2 & 2.5 \\
$\mathrm{CaO}$ & 6.8 & 7.0 & 6.6 & 5.2 \\
$\mathrm{Na}_{2} \mathrm{O}$ & 3.8 & 4.1 & 3.5 & 3.4 \\
$\mathrm{~K}_{2} \mathrm{O}$ & 1.1 & 1.1 & 1.3 & 1.2 \\
\hline
\end{tabular}

part, exhibit systematic compositional trends on Harker-type variation diagrams. Most of this variation is seen in the two compositionally heterogeneous intrusions, the Loma de Cabrera and El Rio batholiths (Fig. 5). Elements showing a decrease with increasing $\mathrm{SiO}_{2}$ in the combined data include nickel and vanadium and to a lesser extent cobalt and zinc. Lead exhibits an increase with increasing $\mathrm{SiO}_{2}$, except in the previously mentioned low-potassium trondjhemites from the El Rio batholith, which form a relatively discrete population (Fig. 5). A curious feature of the trace-element data is the fact that the range

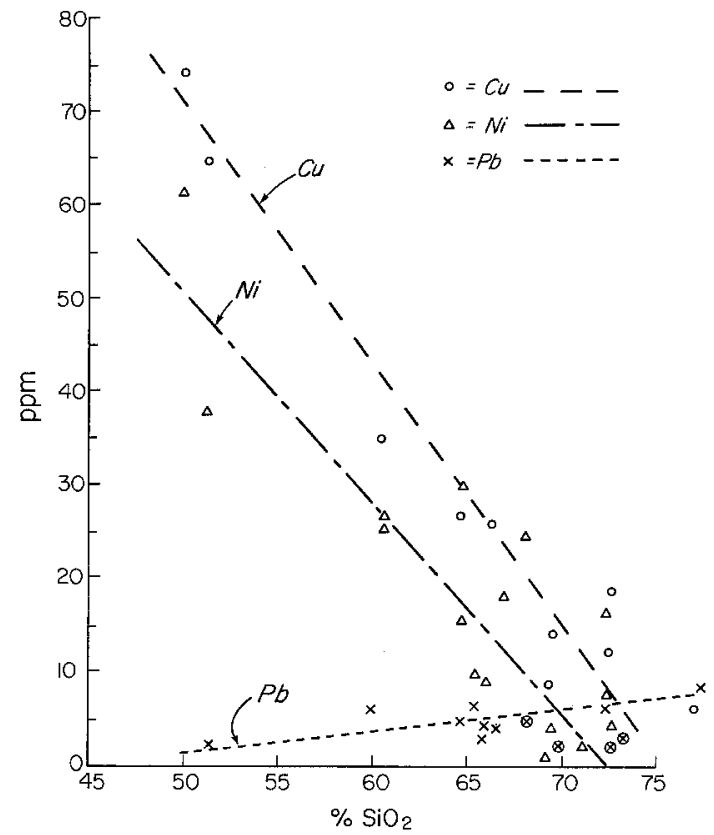

Fig. 5. Variation of selected trace elements with $\mathrm{SiO}_{2}$ in the $\mathrm{El}$ Rio and Loma de Cabrera tonalite intrusions. The circled lead data points are from the trondjhemite samples in the El Rio batholith 
Table 3. Rubidium and strontium geochemistry of intrusive rocks from the Cordillera Central, Dominican Republic

\begin{tabular}{|c|c|c|c|c|c|c|}
\hline $\begin{array}{l}\text { Location and } \\
\text { Sample Number }\end{array}$ & $\begin{array}{l}\mathrm{Rb} \\
(\mathrm{ppm})\end{array}$ & $\begin{array}{l}\mathrm{Sr} \\
(\mathrm{ppm})\end{array}$ & $\mathrm{Rb} / \mathrm{Sr}$ & ${ }^{87} \mathrm{Sr}^{86} \mathrm{Sr}_{\mathrm{m}}{ }^{2}$ & $\left.{ }^{86} \mathrm{Sr}\right|^{88} \mathrm{Sr}$ & ${ }^{87} \mathrm{Sr} r^{86} \mathrm{Sr}_{0}^{b}$ \\
\hline \multicolumn{7}{|l|}{ Medina Stock } \\
\hline RD-72-2 & 42.7 & 500 & 0.0854 & $0.7055^{c}$ & 0.1215 & 0.7052 \\
\hline $\mathrm{RD}-72-4$ & 16.6 & 453 & 0.0366 & 0.7033 & 0.1216 & 0.7033 \\
\hline RD-72-10 & 32.8 & 382 & 0.0859 & $0.7091^{\mathrm{c}}$ & 0.1196 & 0.7088 \\
\hline \multicolumn{7}{|l|}{ El Bao Batholith } \\
\hline $\mathrm{RD}-72-45$ & 17.9 & 338 & 0.0530 & 0.7031 & 0.1204 & 0.7030 \\
\hline $\mathrm{RD}-72-46$ & 19.31 & 401 & 0.0482 & 0.7035 & 0.1212 & 0.7034 \\
\hline \multicolumn{7}{|c|}{ Loma de Cabrera Batholith } \\
\hline RD-72-31 & 51.1 & 129 & 0.396 & 0.7045 & 0.1218 & 0.7034 \\
\hline RD-72-40 & 41.0 & 241 & 0.170 & 0.7034 & 0.1223 & 0.7030 \\
\hline RD-72-41 & 23.9 & 288 & 0.0830 & 0.7040 & 0.1224 & 0.7037 \\
\hline
\end{tabular}

a Measured value normalized to ${ }^{86} \mathrm{Sr} /{ }^{88} \mathrm{Sr}=0.1194$; Eimer and Amend interlaboratory $\mathrm{SrCO}_{3}$ standard, ${ }^{87} \mathrm{Sr} /{ }^{86} \mathrm{Sr}=0.7079 \pm 0.0002$ $(1 \sigma), N=80$

${ }_{b} \quad$ Initial value of ${ }^{87} \mathrm{Sr} /{ }^{86} \mathrm{Sr}$ calculated using rock age of $75 \mathrm{~m} . \mathrm{y}$. and ${ }^{287} \mathrm{Rb}=1.39 \times 10^{-11 \mathrm{yr} .-1}$

- Mean of two analyses. RD-72-2 $=0.7055$ and 0.7054 and RD-72-10 $=0.7091$ and 0.7091 . Observed ${ }^{86} \mathrm{Sr} /{ }^{87} \mathrm{Sr}$ values for these analyses are 0.1211 and 0.1219 for RD-72-2 and 0.1196 and 0.1211 for RD-72-10, respectively. These results, as well as similar results for other samples that have been analyzed in duplicate, indicate that the relatively large range in observed ${ }^{86} \mathrm{Sr} /{ }^{88} \mathrm{Sr}$ values does not have a strong effect on normalized ${ }^{87} \mathrm{Sr} /{ }^{86} \mathrm{Sr}$ values in the mass spectrometric analytical procedure used for our analyses

of copper abundances is similar in both the compositionally heterogeneous (Loma de Cabrera and El Rio) intrusions and in the homogeneous ones. Comparison of our trace-element abundances with the trace element data of Jakes and White (1972) does not help to classify the Dominican Republic tonalites as either calc-alkaline or tholeiitic.

Present day ${ }^{87} \mathrm{Sr} /{ }^{86} \mathrm{Sr}$ ratios for the Dominican Republic intrusive rocks (Table 3 ) range from 0.7031 to 0.7091 . These values do not fall on a well-defined isochron and therefore the rocks cannot be dated with the available strontium isotope data. Initital ratios for the rocks, calculated using an age of $75 \mathrm{~m} . \mathrm{y}$., range from 0.7031 to 0.7088 .

The wide spread in the present day and calculated initial ratios of the pooled data is somewhat misleading. In fact, the two largest intrusions, the Loma de Cabrera and El Bao batholiths, exhibit uniformly low values. In contrast, the smaller Medina stock exhibits calculated initital ratios of 0.7033 to 0.7088 , which range well above the lower values seen in the other two intrusions. None of the Medina samples appear more altered in thin section than other rocks represented in Table 3 and therefore these values probably reflect the original $\mathrm{Sr}$ isotopic composition of their parent magma(s). The possibility that the Medina stock is composite in nature and consists in part of a phase exhibiting low Sr isotope ratios (represented by sample RD-72-4) and a phase exhibiting high $\mathrm{Sr}$ isotope ratios (represented by samples
RD-72-2 and RD-72-10) is supported by limited evidence. For instance, sample RD-72-4 is less potassic than samples 2 and 10 and is the only sample we have from the northwestern third of the stock. The previously mentioned K-Ar results of Kesler, Sutter and Barton include identical ages of $79 \mathrm{~m} . \mathrm{y}$. for samples 2 and 10 but no age for sample 4 . In the absence of a more detailed geochronologic and isotopic study of the Medina stock, we can conclude only that the Medina stock, which is quite small in relation to the El Bao and Loma de Cabrera batholiths, could contain evidence complicating the model discussed below for the origin of the tonalite intrusions.

\section{Origin of the Tonalite Intrusions}

The tonalite magmas could have been derived by partial melting of subducted oceanic crust and overlying sediment, lower crust beneath the host arc, or the underlying mantle. The absence of Precambrian granitic crust in the Greater Antilles has been widely accepted (Donnelly, 1964), which restricts a crustal source for magmas and contaminants to the Mesozoic volcanic and sedimentary rocks of the Greater Antilles island arc and the adjacent ocean basin. K-Ar age data summarized by Kesler et al. (1977a) indicate that the tonalites were emplaced at $75 \pm 10 \mathrm{~m}$.y. into a terrane that is at least $125 \mathrm{~m}$.y. old and which is low in potassium, rubidium and radiogenic strontium. Little evidence can be found in the strontium isotope 
data for a contribution to the tonalite magmas from carbonate oceanic sediment because of the relatively low Sr contents of the rocks (Table 3) and the unrealistically large amounts of assimilation necessary to generate magmas in the $0.705-0.708$ range (Pushkar, 1968, Fig. 4). This, in turn, casts doubt on subducted oceanic crust as a source for the magmas. Further restrictions on magma sources can be made on the basis of thermal considerations. Melting experiments on tonalites indicate that liquidus temperatures of about $1000^{\circ} \mathrm{C}$ are required to form the magmas (Piwinskii and Wyllie, 1970). Such temperatures are unlikely in the lower crust of nascent island arcs such as the Cretaceous Greater Antilles. Hence, a subcrustal or mantle source seems most likely for the tonalite magmas in the Greater Antilles.

The remaining, and currently unresolvable, question concerning the origin of the tonalite magmas centers on the high Sr isotope ratios of the Medina stock. Development of these values by assimilation of oceanic carbonate sediment seems unlikely, as noted above. Instead, it seems probable that the range of $\mathrm{Sr}$ isotope values observed in the Medina stock reflects the heterogeneity of the magma source region. Because evidence for the presence of older granitic crust beneath the Greater Antilles is lacking, we are impelled toward the disturbing tentative conclusion that these variations reflect isotopic variations in the mantle, a possibility that must be evaluated by further, more detailed studies of the Medina stock.

\section{Relation of the Tonalites to Other Island Arc and Continental Margin Intrusive Rocks}

Although the tonalite intrusions exhibit distinctive individual characteristics, they are more similar than different and all fall within the modal and chemical limits of the tonalites. It is possible, in fact, that the presently exposed intrusions in the Cordillera Central represent the upper surface of a more extensive, possibly continuous, batholith underlying the entire Cordillera Central.

Of the other intrusive units in the Greater Antilles, the Cordillera Central batholith is most similar to the Virgin Islands batholith (Longshore, 1966), which is a composite body with the average composition of a mafic tonalite (Table 4). In contrast to these potassium-poor rocks, the granodiorite-quartz monzonite stocks at Terre Neuve, Haiti (Kesler, 1971) and Above Rocks, Jamaica (Reed, 1966) are distinctly potassic. Outcrop area (including submarine extensions) of the Virgin Islands batholith is about $250 \mathrm{~km}^{2}$ and that of the Cordillera Central tonalites (exclusive of the Jautia batholith) is about $1500 \mathrm{~km}^{2}$. In compar-
Table 4. Average composition of the Cordillera Central and Sierra Nevada batholiths. Virgin Islands data from Longshore (1965) and Sierra Nevada data from Dodge (1972)

\begin{tabular}{lccc}
\hline & $\begin{array}{l}\text { Cordillera } \\
\text { Central }\end{array}$ & $\begin{array}{l}\text { Virgin } \\
\text { Islands }\end{array}$ & $\begin{array}{l}\text { Sierra } \\
\text { Nevada }\end{array}$ \\
\hline $\mathrm{SiO}_{2}$ & 62.4 & 58.1 & 68.4 \\
$\mathrm{Al}_{2} \mathrm{O}_{3}$ & 15.1 & 17.1 & 15.3 \\
$\mathrm{TiO}_{2}$ & 0.5 & - & 0.4 \\
$\mathrm{Fe}_{2} \mathrm{O}_{3}{ }^{a}$ & 5.6 & 7.3 & 3.0 \\
$\mathrm{MnO}_{\mathrm{MgO}}$ & 0.1 & - & 0.1 \\
$\mathrm{CaO}$ & 2.7 & 4.1 & 1.2 \\
$\mathrm{Na}$ & 6.5 & 7.5 & 3.2 \\
$\mathrm{~K}$ & $\mathrm{O}$ & 3.4 & 3.4 \\
$\mathrm{Cu}$ & 1.2 & 0.9 & 3.6 \\
$\mathrm{Zn}$ & 67 & - & 20 \\
$\mathrm{~Pb}$ & 46 & - & - \\
$\mathrm{Co}$ & 6 & - & 20 \\
$\mathrm{Ni}$ & 14 & - & 10 \\
$\mathrm{Cr}$ & 17 & - & 10 \\
$\mathrm{~V}$ & 30 & - & 30 \\
\hline
\end{tabular}

Total $\mathrm{Fe}$ as $\mathrm{Fe}_{2} \mathrm{O}_{3}$

ison to outcrop areas of $8 \mathrm{~km}^{2}$ and $55 \mathrm{~km}^{2}$ for the Terre Neuve and Above Rocks stocks, respectively, this conclusively illustrates the preponderance of potassium-poor intrusive rocks in the Greater Antilles.

In comparison to the average composition of another large intrusive complex, the Sierra Nevada batholith of the western U.S., the Cordillera Central tonalites are lower in $\mathrm{SiO}_{2}, \mathrm{~K}_{2} \mathrm{O}$ and $\mathrm{Rb}$ as well as radiogenic strontium (Table 4). Tonalitic intrusions along the western margin of the Sierra Nevada batholith (Kistler and Peterman, 1973) however, are quite similar to those of the Cordillera Central. These intrusions are among the oldest in the Sierra Nevada batholith and their similarity to the Cordillera Central tonalites, which are also the oldest local plutonic units, suggests that such magmas represent the earliest stages in the magmatic evolution of an island arc or active continental margin (regardless of what model is proposed for the origin of the magmas). Some, but not all, younger intrusive rocks in both areas are distinctly more potassic and their development could reflect the increased thickness of the arc crust resulting from sustained igneous activity. Kesler et al. (1977b) have documented a similar compositional evolution of magmatism in the Panamanian island arc.

\section{Conclusions}

Our petrographic and chemical data on four of the oldest plutons in the Cordillera Central of the Dominican Republic indicate that early-arc intrusive magmas were tonalitic in average composition. From 
the standpoint of modal and major element abundances, the four plutons are similar, although two of them (Medina, E1 Bao) are relatively homogeneous, whereas the other two (Loma de Cabrera, El Rio) display a wide variety of rock types. These tonalites are much larger and less potassic than later small granodiorite-quartz monzonite intrusions in the Greater Antilles and appear to represent the bulk of the intrusive rocks in the island arc. In comparison to another large intrusive complex, the Sierra Nevada batholith, the Cordillera Central tonalites are most similar to the earlier, western margin of the batholith. Both major element and isotope chemistry of the tonalites indicate that they were derived largely from a source low in $\mathrm{Rb}$ and with low ${ }^{87} \mathrm{Sr} /{ }^{86} \mathrm{Sr}$ ratios. Thermal considerations suggest that this source was the mantle.

Acknowledgements. Kesler wishes to acknowledge the assistance and support of Robert C. Speck, the National Research Council of Canada and Rosario Resources Corp. with the field work and J.C. Van Loon, Jose Preciado and the National Research Council with the laboratory work at the University of Toronto. Lewis gratefully acknowledges financial support from the Committee on Research at George Washington University and the U.S. National Science Foundation (GA 29199). Wilfred Lundinay assisted with much of the analytical work at the George Washington University. Brian Redmond and Norman Rilling are thanked for logistic support in the Dominican Republic. The mass spectrometric measurements were made in the Analytical Chemistry Division of the Oak Ridge National Laboratory, which is operated for the U.S. Energy Resources and Development Administration by Union Carbide Corporation. Helpful reviews of the manuscript were provided by R.J. Fleck and Z.E. Peterman.

\section{References}

Blesch, R.: Geologic map of the Dominican Republic. In: Reconocimiento y evaluacion de los recursos naturales de la Republica Dominicana: Pan American Union, Washington, D.C., 1967

Bowin, C.O.: Geology of the Central Dominican Republic. Geol. Soc. Am. Mem. 98, 11-84 (1966)

Bowin, C.O.: The geology of Hispaniola. In: Ocean basins and margins (A.E.M. Nairn and F.G. Stehli, eds.), Vol. 3. Gulf of Mexico and Caribbean: Plenum Press 1975

Burke, K., Fox, P.J.: Caribbean ocean floor as a hard-to-subduct remnant. Geol. Soc. Am. Abs. Prog. 8, No. 6, 795-796 (1976)

Cheilletz, A., Lewis, V.F.: Contribution a l'etude de la bordure meridionale du Massif du Nord, Nord-est d'Haiti. Proc. of 1975 Carib. Geol. Conf. Guadeloupe 1975
Cox, D.P., Marvin, R.F., McGonigle, J.W,, McIntyre, D.H., Rogers, C.L.: Potassium-argon geochrononology of metamorphic, igneous and hydrothermal events in Puerto Rico and the Virgin Islands. Res. U.S.G.S., in press 1977

Dodge, F.C.W.: Trace-element contents of some plutonic rocks of the Sierra Nevada batholith. U.S. Geol. Surrey Bull. 1314-F, p. $13(1972)$

Donnelly, T.W.: Evolution of the eastern Antillean island arc. Am. Ass. Petrol. Geol. Bull. 48, 680-696 (1964)

Donnelly, T.W., Rogers, J.J.W., Pushkar, P., Armstrong, R.L.: Chemical evolution of the igneous rocks of the eastern West Indies. Geol. Soc. Am. Mem. 130, 181-224 (1971)

Jakes, P., White, A.J.R.: Major and trace element abundances in volcanic rocks of orogenic areas. Geol. Soc. Am. Bull. 83, 29-40 (1972)

Kesler, S.E.: Petrology of the Terre-Neuve igneous province, northern Haiti. Geol. Soc. Am. Mem. 130, 119-138 (1971)

Kesler, S.E., Sutter, J.F., Issigonis, M.J., Jones, L.M., Walker, R.L.: Evolution of porphyry copper mineralization in an oceanic island arc: Panama Econ. Geol. 72, in press 1977 b

Kesler, S.E., Sutter, J.F., Jones, L.M., Walker, R.L.: Early Cretaceous basement rocks in Hispaniola. Geology 5, 245-247 (1977a)

Khudoley, D.M., Meyerhoff, A.A.: Paleogeography and geological history of Greater Antilles. Geol. Soc. Am. Mem. 129, p. 199 (1971)

Kistler, R.W., Peterman, Z.E.: Variations in Sr, Rb, K, Na and initital $\mathrm{Sr}^{87} / \mathrm{Sr}^{86}$ in Mesozoic granitic rocks and intruded wall rocks in central California. Geol. Soc. Am. Bull. 84, 3489-3512 (1973)

Longshore, J.D.: Chemical and mineralogical variations in the Virgin Islands batholith and its associated wall rocks. Unpublished Ph.D. dissertation, Rice Univ. p. 94 (1965)

Malfait, B.T., Dinkelman, M.G.: Circum-Caribbean tectonic and igneous activity and the evolution of the Caribbean plate. Geol. Soc. Am. Bull. 83, 251-272 (1972)

Miyashiro, A.: Volcanic rock series in island arcs and active continental margins. Am. J. Sci. 274, 321-355 (1974)

Palmer, H.C.: Geology of the Moncion-Jarabacoa area, Dominican Republic. Unpublished Ph.D. dissertation, Princeton University, p. 256 (1963)

Peacock, M.A.: Classification of igneous rock series. J. Geol, 39, 421-426 (1931)

Piwinskii, A.J., Wyllie, P.J. : Experimental studies of igneous rock series. J. Geol. 78, 52-76 (1970)

Pushkar, P.: Strontium isotope ratios in volcanic rocks of three island arc areas. J. Geophys. Res. 73, 2701-2714 (1968)

Reed, A.J.: Geology of the Bog Walk Quadrangle, Jamaica. Geol. Survey Dept. of Jamaica Bull. No. 6, p. 54 (1966)

Weyl, R.: Geologie der Antillen p. 410, Berlin: Gebruder Borntraeger 1966

Received May 20, 1976; Accepted September 15, 1977 